CZASOPISMO INŻYNIERII LA¿DOWEJ, ŚRODOWISKA I ARCHITEKTURY JOURNAL OF CIVIL ENGINEERING, ENVIRONMENT AND ARCHITECTURE

JCEEA, t. XXXIV, z. 64 (2/II/17), kwiecień-czerwiec 2017, s. 267-297, DOI: 10.7862/rb.2017.98

\author{
Agnieszka WIATER ${ }^{1}$
}

Tomasz SIWOWSKI ${ }^{2}$

\title{
NOŚNOŚĆ NA ŚCINANIE ZGINANYCH ELEMENTÓW BETONOWYCH ZBROJONYCH PRETTAMI KOMPOZYTOWYMI FRP W ŚWIETLE WYBRANYCH PROCEDUR OBLICZENIOWYCH
}

\begin{abstract}
Pręty kompozytowe FRP (ang. fibre reinforced polymer) ze względu na wysoką wytrzymałość i odporność na korozję są obiecującą alternatywą dla tradycyjnego zbrojenia betonu i mają coraz szersze zastosowanie. W projektowaniu elementów betonowych zbrojonych prętami FRP na szczególną uwagę zasługuję zagadnienie nośności na ścinanie. Ścinanie jest zjawiskiem złożonym w konstrukcjach żelbetowych, a w przypadku zbrojenia kompozytowego opis mechanizmów jest jeszcze trudniejszy ze względu na liniowo sprężystą charakterystykę i anizotropowe właściwości prętów FRP. W pracy przeprowadzono przegląd procedur obliczeniowych dotyczących określania nośności na ścinanie elementów betonowych zbrojonych prętami kompozytowymi, bez zbrojenia poprzecznego. Wyodrębniono trzy grupy procedur: (I) będące modyfikacją wzorów stosowanych w przypadku konstrukcji żelbetowych, (II) będące modyfikacją istniejących procedur projektowych dla elementów zbrojonych prętami FRP oraz (III) wzorów opracowanych w oparciu o analizę wyników badań doświadczalnych i zastosowania różnych narzędzi obliczeniowych. Przedstawiono analizę sposobu uwzględniania w dostępnych procedurach obliczeniowych wpływu parametrów zmiennych przekroju elementu, m.in. geometria elementu, smukłość ścinania, stopień zbrojenia podłużnego, moduł Younga kompozytu FRP oraz wytrzymałość betonu na ściskanie. Porównano wartości wyznaczone wybranymi procedurami i podjęto próbę określenia przyczyn wykazanych rozbieżności. Przeanalizowano również procedury uwzględniające zastosowanie betonu lekkiego i porównano wyznaczone według nich wartości z wynikami własnych badań doświadczalnych. Na podstawie przeprowadzonych analiz wykazano konieczność prowadzenia dalszych badań nad nośnością na ścinanie elementów $\mathrm{z}$ betonu lekkiego zbrojonego prętami kompozytowymi.
\end{abstract}

Słowa kluczowe: zbrojenie niemetaliczne, kompozyt FRP, nośność na ścinanie, procedura obliczeniowa, beton lekki

${ }^{1}$ Autor do korespondencji / corresponding author: Agnieszka Wiater, Politechnika Rzeszowska, Zakład Dróg i Mostów, ul. Poznańska 2, 35-959 Rzeszów; tel. 178651017; wiater@ prz.edu.pl

2 Tomasz Siwowski, Politechnika Rzeszowska, Zakład Dróg i Mostów, ul. Poznańska 2, 35-959 Rzeszów; tel. 178651019; siwowski@prz.edu.pl 


\section{Wprowadzenie}

Pręty kompozytowe FRP (ang. fibre reinforced polymer) ze względu swoje doskonałe własności mechaniczne i fizyczne stały się ostatnio obiecującą alternatywą dla tradycyjnego zbrojenia stalowego konstrukcji betonowych. W zależności od użytych włókien produkuje się obecnie pręty z kompozytów szklanych (GFRP), węglowych (CFRP), aramidowych (AFRP) oraz bazaltowych (BFRP). Osnowę włókien stanowią najczęściej żywica poliestrowa, winyloestrowa lub epoksydowa. Ze względu na różnicę w składzie kompozytów pręty FRP różnią się między sobą własnościami mechanicznymi i fizycznymi [41]. Najszersze zastosowanie $\mathrm{w}$ budownictwie mają pręty $\mathrm{z}$ kompozytów szklanych GFRP, głównie ze względu na najlepszy stosunek wytrzymałości do ceny. W porównaniu z prętami stalowymi można wymienić wiele zalet prętów kompozytowych, takich jak wysoka wytrzymałość, duża odporność na korozję, odporność chemiczna, neutralność elektromagnetyczna oraz mała masa. Wymienione cechy prętów kompozytowych zapewniają wysoką trwałość betonowych elementów konstrukcyjnych zbrojonych tymi prętami oraz redukcję kosztów utrzymania obiektów w cyklu życia, co jest coraz częściej główną przyczyną ich stosowania np. w obiektach mostowych [16]. Zbrojenie kompozytowe GFRP jest już od kilkunastu lat szeroko stosowane jako zbrojenie płyt pomostów obiektów mostowych w Kanadzie, USA czy Japonii. Zastosowanie prętów kompozytowych w obiektach mostowych opisano szeroko między innymi w pracy [33].

Praca pod obciążeniem betonowych elementów zginanych, zbrojonych prętami kompozytowymi, różni się od pracy elementów żelbetowych i wynika z własności zbrojenia kompozytowego, które nie uplastycznia się i pracuje liniowo sprężyście aż do zniszczenia. Podobnie jak w przypadku żelbetu podstawą do wyznaczenia nośności na zginanie elementów betonowych zbrojonych prętami kompozytowymi jest rozkład naprężeń w przekroju w fazie poprzedzającej zniszczenie. W projektowaniu elementów betonowych zbrojonych prętami kompozytowymi stosuje się takie same założenia, jak w przypadku zbrojenia stalowego, tj.:

- przekroje płaskie przed odkształceniem pozostają płaskie po odkształceniu,

- zapewniona jest pełna współpraca pomiędzy betonem a prętem zbrojeniowym,

- naprężenia w materiałach (beton, pręt FRP) przyjmuje się na podstawie odkształceń w przekroju i odpowiednich praw materiałowych,

- wytrzymałość betonu na rozciąganie jest pomijalna.

W przypadku żelbetu zniszczenie elementu jest kontrolowane przez zmiażdżenie betonu poprzedzające lub następujące po uplastycznieniu stali, natomiast w elementach zbrojonych kompozytem FRP zniszczenie może nastąpić w wyniku zmiażdżenia betonu i/lub przerwania prętów kompozytowych. W rezultacie materiał (beton lub zbrojenie FRP) który pierwszy osiągnie graniczne odkształcenie, determinuje postać zniszczenia elementu. Obie postaci zniszczenia mają charakter nagły i niesygnalizowany, jednak ze względów bezpieczeństwa zale- 
canym mechanizmem stanowiącym podstawę analizy nośności przekroju jest wyczerpanie wytrzymałości betonu na ściskanie. Elementy zbrojone prętami FRP wykazują większe ugięcia i rozwartości rys niż w przypadku żelbetu. Jednakże jeżeli podstawą wyznaczania nośności na zginanie jest model zniszczenia poprzez zmiażdżenie betonu, kryteria stanu granicznego użytkowalności są zazwyczaj spełnione. W przypadku nośności na ścinanie w wyniku zastosowania zbrojenia FRP, które może charakteryzować się 3-krotnie niższym modułem sprężystości niż stal zbrojeniowa, przekrój zarysowany ma mniejszą wysokość strefy ściskanej w odniesieniu do elementów ze zbrojeniem stalowym. Zmniejszenie wysokości strefy ściskanej przekroju skutkuje zwiększeniem rozwartości rys, w rezultacie czego nośność elementu zapewniona przez zakleszczanie się kruszywa i strefę ściskaną przekroju jest mniejsza niż w przypadku konstrukcji żelbetowych. Pomimo kilkunastu lat stosowania prętów FRP w obiektach budowlanych, nadal jest poszukiwany racjonalny model opisujący mechanizmy zniszczenia przez ścinanie elementów betonowych zbrojonych prętami kompozytowymi, który posłużyłby do szacowania ich nośności na ścinanie [34].

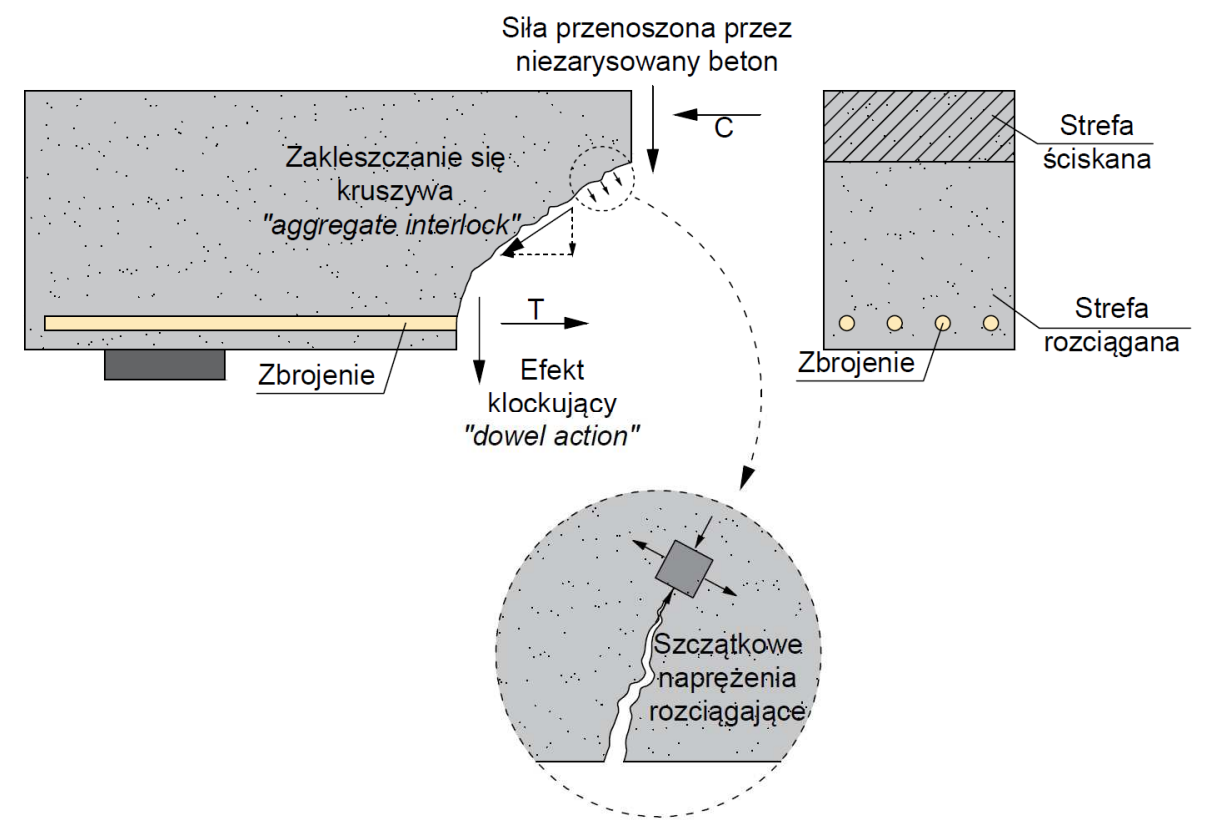

Rys. 1. Mechanizmy zapewniające nośność elementów żelbetowych na ścinanie

Fig. 1. Shear mechanism of reinforced concrete members

Zagadnienie ścinania $w$ konstrukcjach żelbetowych jest zjawiskiem złożonym, związanym $\mathrm{z}$ jednoczesnym występowaniem kilku mechanizmów wewnętrznych. Można wymienić pięć podstawowych mechanizmów mających wpływ na przenoszenie siły ścinającej przez zbrojony przekrój betonowy 
(Rys. 1). Są to: (a) przenoszenie siły przez strefę ściskaną betonu niezarysowanego, (b) przenoszenie siły przez tarcie wzdłuż rysy spowodowane zakleszczaniem się kruszywa (ang. aggregate interlock), (c) przenoszenie siły dzięki szczątkowej wytrzymałości na rozciąganie betonu w poprzek rysy, (d) przenoszenie siły przez poprzeczną pracę zbrojenia podłużnego, tzw. efekt klockujący (ang. dowel action), (e) przenoszenie siły przez zbrojenie poprzeczne (jeśli występuje) [10], [26]. Te same mechanizmy występują w konstrukcjach betonowych zbrojonych prętami kompozytowymi, jednak ich zakres i tym samym wpływ na nośność elementu są inne.

Piśmiennictwo dotyczące zjawiska ścinania w konstrukcjach żelbetowych jest bardzo obszerne. Pomimo tego złożoność opisanego mechanizmu stanowi główny problem w prognozowaniu nośności na ścinanie elementów betonowych oraz jest powodem ciągłych poszukiwań lepszego opisu tego zjawiska. Dostępne procedury normowe dotyczące konstrukcji żelbetowych niekiedy budzą wątpliwości i nie opisują wystarczająco dokładnie występujących mechanizmów, a tym samym dość często wykazują zbyt duży konserwatyzm [26]. Ponadto procedury te nie mogą być bezpośrednio zastosowane do projektowania elementów betonowych ze zbrojeniem kompozytowym, co jest spowodowane innymi własnościami mechanicznymi prętów FRP w porównaniu ze zbrojeniem stalowym. Dlatego też konstrukcje betonowe zbrojone prętami kompozytowymi wymagają opracowania indywidualnych procedur obliczeniowych [49].

Szeroką analizę wpływu różnych parametrów na mechanizm zniszczenia oraz nośność na ścinanie belek zbrojonych prętami kompozytowymi przedstawiono w pracy [27]. Na podstawie wyników badań 203 belek zbrojonych prętami szklanymi, węglowymi, aramidowymi oraz stalowymi, przeanalizowano wpływ smukłości ścinania, rodzaju i stopnia zbrojenia podłużnego, wytrzymałości betonu na ściskanie oraz wymiarów elementu na nośność belek na ścinanie. Autorzy wykazali podstawowe różnice w nośności na ścinanie elementów betonowych, zbrojonych prętami kompozytowymi i stalowymi. W odróżnieniu od konstrukcji żelbetowych, mechanizm zniszczenia na ścinanie elementów betonowych ze zbrojeniem kompozytowym ma łagodniejszy charakter i następuje w sposób mniej nagły. Na podstawie analizy piśmiennictwa stwierdzono brak badań nad wpływem na nośność na ścinanie takich parametrów jak: pole przekroju zbrojenia kompozytowego, przyczepność zbrojenia do betonu oraz liczba prętów i liczba poziomów zbrojenia. Wskazano potrzebę prowadzenia dalszych badań i analiz ze względu na istotne różnice w nośności na ścinanie elementów betonowych zbrojonych prętami kompozytowymi i stalowymi [27].

W niniejszej pracy podjęto próbę analizy dostępnych procedur obliczeniowych, mających na celu określenie nośności na ścinanie elementów betonowych ze zbrojeniem kompozytowym bez zbrojenia poprzecznego. Ponieważ, jak wykazały badania przedstawione w pracach [19] i [40], szerokość elementu ma nieznaczny wpływ na jego nośność na ścinanie, opisane procedury mogą mieć zastosowanie zarówno do belek jak i płyt betonowych. 
Analizowane procedury obliczeniowe podzielono na trzy zasadnicze grupy:

(I) procedury będące modyfikacją metod stosowanych w konstrukcjach żelbetowych (z prętami stalowymi);

(II) procedury będące modyfikacją metod stosowanych w elementach zbrojonych prętami kompozytowymi;

(III) procedury opracowane na podstawie wyników badań eksperymentalnych oraz z wykorzystaniem specjalistycznych analiz, wspomaganych różnymi narzędziami obliczeniowymi ( $\mathrm{m}$. in. programowanie genetyczne, sieci neuronowe, itp.).

Na podstawie przeglądu procedur zestawionych w tych trzech grupach ustalono wpływ głównych parametrów przekroju poprzecznego elementu na jego nośność na ścinanie oraz zidentyfikowano obszary wymagające dalszych badań i analiz.

$\mathrm{W}$ procedurach obliczeniowych opisanych w dalszej części pracy przyjęto następujące oznaczenia (ujednolicone):

$a$ - odległość punktu przyłożenia obciążenia od punktu podparcia;

$a_{g}$ - maksymalny wymiar kruszywa w mieszance betonowej,

$a / d$ - smukłość ścinania, tj. stosunek odległości punktu przyłożenia obciążenia od punktu podparcia do wysokości użytecznej przekroju;

$A_{f}$ - pole przekroju zbrojenia kompozytowego;

$b_{w}$ - szerokość przekroju lub szerokość środnika belki teowej;

$d$ - wysokość użyteczna przekroju, tj. odległość środka ciężkości zbrojenia rozciąganego od najbardziej ściskanej krawędzi betonu;

$E_{c}$ - moduł sprężystości betonu;

$E_{f}$ - moduł sprężystości zbrojenia kompozytowego;

$E_{s}$ - moduł sprężystości zbrojenia stalowego;

$f_{c}$ - wytrzymałość betonu na ściskanie;

$f_{c t}$ - wytrzymałość betonu na rozciąganie;

$h$ - wysokość przekroju;

$M$ - moment zginający w analizowanym przekroju;

$V$ - siła poprzeczna w analizowanym przekroju;

$V_{c}$ - nośność na ścinanie elementów bez zbrojenia poprzecznego;

$\varepsilon_{y}$ - graniczne odkształcenie stali zbrojeniowej;

$\lambda$ - współczynnik redukcyjny dla betonów lekkich;

$\rho_{f}$ - stopień podłużnego zbrojenia kompozytowego elementu, tj. stosunek pola przekroju zbrojenia podłużnego do szerokości i wysokości użytecznej przekroju;

$\rho_{s}$ - stopień podłużnego zbrojenia stalowego elementu, definiowany identycznie jak w przypadku zbrojenia FRP.

Przytoczone wzory pozwalają określić charakterystyczną nośność na ścinanie elementów betonowych zbrojonych prętami kompozytowymi bez zbrojenia poprzecznego, pomijając współczynniki bezpieczeństwa przyjmowane w poszczególnych normach. 


\section{Przegląd procedur obliczeniowych}

\subsection{Procedury będące modyfikacją metod stosowanych w konstrukcjach żelbetowych}

Procedury obliczeniowe nośności na ścinanie elementów betonowych zbrojonych prętami FRP powstałe na podstawie modyfikacji wzorów dotyczących konstrukcji żelbetowych zestawiono w tabeli $1 \mathrm{w}$ kolejności chronologicznej. Przede wszystkim należy podkreślić, że już same wzory podstawowe - dotyczące obliczania nośności na ścinanie elementów żelbetowych, różnią się znacząco. W tym kontekście różnorodność zastosowanych modyfikacji tych wzorów dla elementów zbrojonych prętami kompozytowymi różnice te tylko powiększyło. Warto jednak przeanalizować chociażby główne kierunki tych modyfikacji, aby zidentyfikować parametry przekroju zbrojonego, które w największym stopniu takiej modyfikacji podlegały.

Zestawione w tabeli 1 wzory na obliczenie nośności na ścinanie elementów betonowych zbrojonych prętami kompozytowymi powstały w wyniku modyfikacji wzorów na nośność na ścinanie elementów żelbetowych przez:

- zastąpienie stopnia zbrojenia stalą $\rho_{s}$ przez znormalizowany stopień zbrojenia kompozytem $\rho_{f}\left(E_{f} / E_{s}\right)$ - poz. 1, 2, 4, 7 (pośrednio uwzględniając typową wartość modułu Younga zbrojenia stalowego $E_{s}$ ), poz. 10, 13, 20, tabela 1;

- zmianę wartości nośności na ścinanie $V_{c}$ przez wprowadzenie współczynnika $a\left(E_{f} / E_{s}\right)^{n} \mathrm{z}$ odpowiednio dobraną wartością mnożnika $a$ i wykładnika potęgi $n$ - poz. $3(a=1 ; n=1)$, poz. $5(a=3 ; n=1)$, poz. $6(a=1 ; n=0,5)$, poz. 12 $(a=1,3 ; n=0,5)$, poz. $17(a=1,65 ; n=0,6)$, poz. $19(a=1 ; n=1 / 3)$, tabela 1 ;

- zmianę wartości nośności na ścinanie $V_{c}$ za pomocą stosunku sztywności zbrojenia kompozytowego do sztywności zbrojenia stalowego $\left(\rho_{f} E_{f} \rho \rho_{s} E_{s}\right)$ - poz. 8, 9, tabela 1;

- zmianę wartości nośności na ścinanie $V_{c}$ przez wprowadzenie współczynnika redukcyjnego w postaci $\left(\frac{E_{f}}{E_{s}} \cdot \frac{4,5 \% 0}{\varepsilon_{y}}\right)^{1 / 3}$, uwzględniającego stosunek modułów kompozytu i stali zbrojeniowej $\left(E_{f} / E_{s}\right)$ oraz dopuszczalne odkształcenie zbrojenia kompozytowego, przyjęte na poziomie $4,5 \%$, w stosunku do odkształcenia uplastyczniającego stali zbrojeniowej $\left(\varepsilon_{y}\right)$ - poz. 11, tabela 1 ;

- adaptację metody MCFT (ang. modified compression field theory), stosując współczynnik $\sqrt{\frac{E_{f}}{E_{s}}}$ - poz. 14, tabela 1; lub uwzględniającą większy zakres odkształceń granicznych prętów FRP niż w przypadku zbrojenia stalowego poz. 15 , tabela 1 ;

- zmianę wartości nośności na ścinanie $V_{c}$ za pomocą współczynnika, uwzględniającego w inny sposób (niż wymienione wyżej metody) dane parametry: stosunek modułów sprężystości kompozytu i stali $\left(E_{f} / E_{s}\right)$, smukłość ścinania $(a / d)$ oraz stopień zbrojenia elementu $\left(\rho_{f}\right)$ - poz. 16 , tabela 1 ; smukłość ścina- 
nia $(a / d)$ oraz moduł sprężystości zbrojenia kompozytowego $E_{f}$ - poz. 18 , tabela 1 .

$\mathrm{Na}$ podstawie analizy procedur obliczeniowych zestawionych $\mathrm{w}$ tabeli 1 można stwierdzić, że głównym kierunkiem modyfikacji wzorów dla konstrukcji żelbetowych było zastosowanie stosunku modułów sprężystości kompozytu i stali $\left(E_{f} / E_{s}\right)$ do redukcji stopnia zbrojenia elementu $\rho_{s}$ lub bezpośrednio redukcji nośności na ścinanie $V_{c}$. W niektórych wzorach uwzględniano także różnicę w odkształcalności obu materiałów - za pomocą ilorazu dopuszczalnych odkształceń $\mathrm{w}$ zbrojeniu kompozytowym i odkształceń uplastyczniających stal zbrojeniową.

Tabela 1. Procedury obliczeniowe nośności na ścinanie elementów betonowych zbrojonych prętami FRP będące modyfikacją metod stosowanych w konstrukcjach żelbetowych

Table 1. The shear prediction models of FRP reinforced concrete members, which are modification of design equations for the steel reinforced construction

\begin{tabular}{|c|c|c|c|c|}
\hline Lp. & Procedura & \multicolumn{3}{|l|}{ Wzór } \\
\hline 1. & $\begin{array}{l}\text { Tottori i in. } \\
\quad(1993) \\
{[43]}\end{array}$ & $V_{c}=0,2\left(100 \rho_{f} f_{c} \frac{E_{f}}{E_{s}}\right)^{\frac{1}{3}}\left(\frac{d}{1000}\right)^{-\frac{1}{4}}$ & $0,75+\frac{1,4}{\left(\frac{a}{d}\right)}$ & $b_{w} d$ \\
\hline 2. & $\begin{array}{c}\text { JSCE-97 } \\
(1997) \\
{[24]}\end{array}$ & $\begin{array}{l}V_{c}=\beta_{d} \beta_{p} \beta_{n} f_{v c d} b_{w} d \\
\text { gdzie: } \\
\beta_{d}=\sqrt[4]{1 / d[m]} \leq 1,5 \\
\beta_{p}=\sqrt[3]{100 \rho_{f} E_{f} / E_{s}} \leq 1,5 \\
\beta_{n}=1,0, \text { w przypadku braku siły osio } \\
f_{v c d}=0,2 \sqrt[3]{f_{c}} \leq 0,72 \mathrm{~N} / \mathrm{mm}^{2}\end{array}$ & wej & \\
\hline 3. & $\begin{array}{c}\text { Michaluk i in. } \\
\text { (1998) } \\
{[32]}\end{array}$ & $\mathrm{V}_{\mathrm{c}}=\frac{E_{f}}{E_{s}}\left(\frac{1}{6} \sqrt{f_{c}} b_{w} d\right)$ & & \\
\hline 4. & $\begin{array}{l}\text { IStructE } \\
(1999) \\
{[21]}\end{array}$ & $\begin{array}{l}V_{c}=0,79\left(100 \rho_{f} \frac{E_{f}}{E_{s}}\right)^{\frac{1}{3}}\left(\frac{400}{d}\right)^{\frac{1}{4}}( \\
\text { gdzie: } \\
f_{c u}=1,25 f_{c}\end{array}$ & $\left.\frac{f_{c u}}{25}\right)^{\frac{1}{3}} b_{w} d$ & \\
\hline
\end{tabular}


Tabela 1 (cd.). Procedury obliczeniowe nośności na ścinanie elementów betonowych zbrojonych prętami FRP będące modyfikacją metod stosowanych w konstrukcjach żelbetowych

Table 1 (cont.). The shear prediction models of FRP reinforced concrete members, which are modification of design equations for the steel reinforced construction

\begin{tabular}{|c|c|c|}
\hline Lp. & Procedura & Wzór \\
\hline 5. & $\begin{array}{l}\text { Deitz i in. } \\
\text { (2001) } \\
\text { [12] }\end{array}$ & $\mathrm{V}_{\mathrm{c}}=3 \frac{E_{f}}{E_{s}}\left(\frac{1}{6} \sqrt{f_{c}} b_{w} d\right)$ \\
\hline 6. & $\begin{array}{c}\text { ISIS } \\
(2001,2007) \\
{[22]}\end{array}$ & $\begin{array}{l}\text { Dla } d<300 \mathrm{~mm}: \\
V_{c}=0,2 \lambda \sqrt{f_{c}} b_{w} d \sqrt{\frac{E_{f}}{E_{s}}} \\
\text { Dla } d>300 \mathrm{~mm}: \\
V_{c}=\left(\frac{260}{1000-d}\right) \lambda \sqrt{f_{c}} b_{w} d \sqrt{\frac{E_{f}}{E_{s}}} \geq 0,1 \lambda \sqrt{f_{c}} b_{w} d \sqrt{\frac{E_{f}}{E_{s}}}\end{array}$ \\
\hline 7. & $\begin{array}{c}\text { CSA-S806-02 } \\
{[7]}\end{array}$ & $\begin{array}{l}\text { Dla } d<300 \mathrm{~mm} \text { : } \\
V_{c}=0,035 \lambda\left(f_{c} \rho_{f} E_{f} \frac{V}{M} d\right)^{\frac{1}{3}} b_{w} d \\
\text { Przy czym: } \\
\frac{V}{M} d \leq 1,0 \\
\text { oraz spełniony jest warunek: } \\
0,1 \lambda \sqrt{f_{c}} b_{w} d \leq V_{c} \leq 0,2 \lambda \sqrt{f_{c}} b_{w} d \\
\text { Dla } d>300 \mathrm{~mm}: \\
V_{c}=\left(\frac{130}{1000+d}\right) \lambda \sqrt{f_{c}} b_{w} d \geq 0,08 \lambda \sqrt{f_{c}} b_{w} d\end{array}$ \\
\hline 8. & $\begin{array}{c}\mathrm{ACI} \text { 440.1R-03 } \\
{[2]}\end{array}$ & $\begin{array}{l}V_{c}=\frac{\rho_{f} E_{f}}{90 \beta_{1} f_{c}}\left(\frac{\sqrt{f_{c}} b_{w} d}{6}\right) \\
\text { gdzie: } \\
\beta_{1}=\left\{\begin{array}{ccc}0,85 & \text { dla } & f_{c} \leq 28[\mathrm{MPa}] \\
0,85-0,05 \frac{f_{c}-28[\mathrm{MPa}]}{7[\mathrm{MPa}]} & \text { dla } & f_{c}=28 \div 56[\mathrm{MPa}] \\
0,65 & \text { dla } & f_{c} \geq 56[\mathrm{MPa}]\end{array}\right.\end{array}$ \\
\hline
\end{tabular}


Tabela 1 (cd.). Procedury obliczeniowe nośności na ścinanie elementów betonowych zbrojonych prętami FRP będące modyfikacją metod stosowanych w konstrukcjach żelbetowych

Table 1 (cont.). The shear prediction models of FRP reinforced concrete members, which are modification of design equations for the steel reinforced construction

\begin{tabular}{|c|c|c|}
\hline Lp. & Procedura & Wzór \\
\hline 9. & $\begin{array}{c}\text { ECP 208 } \\
(2005) \\
{[13]}\end{array}$ & $\begin{array}{l}V_{c}=0,24 \sqrt{f_{c}}\left(\frac{\rho_{f} \cdot E_{f}}{\rho_{s} \cdot E_{s}}\right) b_{w} d \\
\text { gdzie: } \\
\rho_{s}=5 \cdot 10^{-4} f_{c}\end{array}$ \\
\hline 10. & $\begin{array}{c}\text { Wegian } \mathrm{i} \text { in. } \\
\quad(2005) \\
{[46]}\end{array}$ & $V_{c}=2\left(f_{c} \frac{\rho_{f} E_{f}}{E_{s}} \frac{d}{a}\right)^{\frac{1}{3}} b_{w} d$ \\
\hline 11. & $\begin{array}{c}\text { Guadagnini } \\
\text { i in. (2006) } \\
{[18]}\end{array}$ & $\begin{array}{l}\text { Eurokod 2: } \\
V_{c}=0,18\left(1+\sqrt{\frac{200}{d}}\right)\left(100 \frac{A_{f}}{b_{w} d} \frac{E_{f}}{E_{s}} \frac{4,5 \%}{\varepsilon_{y}} f_{c}\right)^{1 / 3} b_{w} d \\
\text { BS 8110: } \\
V_{c}=0,79\left(100 \rho_{f} \frac{E_{f}}{200} \frac{4,5 \%}{\varepsilon_{y}}\right)^{\frac{1}{3}}\left(\frac{400}{d}\right)^{\frac{1}{4}}\left(\frac{f_{c u}}{25}\right)^{\frac{1}{3}} b_{w} d \\
\text { gdzie: } \\
f_{c u}=1,25 f_{c} \\
\text { ACI } 318-05: \\
V_{c}=\left(\frac{E_{f}}{E_{s}} \cdot \frac{4,5 \%}{\varepsilon_{y}}\right)^{\frac{1}{3}} \cdot \frac{1}{6} \cdot \sqrt{f_{c}} \cdot b_{w} d\end{array}$ \\
\hline
\end{tabular}


Tabela 1 (cd.). Procedury obliczeniowe nośności na ścinanie elementów betonowych zbrojonych prętami FRP będące modyfikacją metod stosowanych w konstrukcjach żelbetowych

Table 1 (cont.). The shear prediction models of FRP reinforced concrete members, which are modification of design equations for the steel reinforced construction

\begin{tabular}{|c|c|c|}
\hline Lp. & Procedura & Wzór \\
\hline 12. & $\begin{array}{c}\text { CNR DT } 203 \text { - } \\
2006 \\
{[11]}\end{array}$ & $\begin{array}{l}V_{c}=\min \left(V_{R d, c t} ; V_{R d, \text { max }}\right) \\
V_{R d, c t}=1,3\left(\frac{E_{f}}{E_{s}}\right)^{\frac{1}{2}} \tau_{R d} k_{d}\left(1,2+40 \rho_{f}\right) b_{w} d \\
V_{R d, \text { max }}=0,5 \cdot v_{1} \cdot f_{c} \cdot b_{w} \cdot 0,9 d \\
\text { gdzie: } \\
\tau_{R d}=0,25 f_{c t} \\
k_{d}=1,6-d[\mathrm{~m}] \geq 1 \\
v_{1}=\left\{\begin{array}{lll}0,6 & \text { dla } & f_{c} \leq 60[\mathrm{MPa}] \\
0,9-\frac{f_{c}}{200} \geq 0,5 & \text { dla } & f_{c}>60[\mathrm{MPa}]\end{array}\right. \\
\text { Przy czym: } \\
1,3\left(\frac{E_{f}}{E_{s}}\right)^{\frac{1}{2}} \leq 1\end{array}$ \\
\hline 13. & $\begin{array}{l}\text { Nehdi i in. } \\
\text { (2007) } \\
\text { [36] }\end{array}$ & $\begin{array}{l}V_{c}=2,1\left(\frac{f_{c}^{\prime} \cdot \rho_{f} \cdot d}{a} \cdot \frac{E_{f}}{E_{s}}\right)^{0,3} \cdot b_{w} \cdot d \\
g d y \quad a / d>2,5 \quad V_{c}^{\prime \prime}=2,5 \frac{d}{a} V_{c}\end{array}$ \\
\hline
\end{tabular}


Tabela 1 (cd.). Procedury obliczeniowe nośności na ścinanie elementów betonowych zbrojonych prętami FRP będące modyfikacją metod stosowanych w konstrukcjach żelbetowych

Table 1 (cont.). The shear prediction models of FRP reinforced concrete members, which are modification of design equations for the steel reinforced construction

\begin{tabular}{|c|c|c|}
\hline Lp. & Procedura & Wzór \\
\hline 14. & $\begin{array}{c}\text { CSA S6-06 } \\
{[6]}\end{array}$ & $\begin{array}{l}V_{c}=2.5 \cdot \beta \cdot f_{c r} \cdot b_{w} \cdot d_{v} \cdot \sqrt{E_{f} / E_{s}} \\
\beta=\frac{0,4}{\left(1+1500 \varepsilon_{x}\right)} \cdot \frac{1300}{\left(1000+s_{z e}\right)} \\
\text { gdzie: } \\
f_{c r}=0,4 \sqrt{f_{c}} \\
\varepsilon_{x}=\frac{M / d_{v}+V}{2 \cdot E_{f} \cdot A_{f}} \\
s_{z e}=\frac{35 d_{v}}{15+a_{g}} \\
d_{v}=0,9 \cdot d\end{array}$ \\
\hline 15. & $\begin{array}{c}\text { Hoult } \mathrm{i} \text { in. } \\
(\mathbf{2 0 0 8}) \\
{[20]}\end{array}$ & $\begin{array}{l}V_{c}=\frac{0,3}{0,5+\left(1000 \cdot \varepsilon_{x}+0,15\right)^{0,7}} \cdot \frac{1300}{\left(1000+s_{z e}\right)} \cdot \sqrt{f_{c}} \cdot b_{w} \cdot d_{v} \\
\text { gdzie: } \\
\varepsilon_{x}=\frac{M / d_{v}+V}{2 \cdot E_{f} \cdot A_{f}} \\
s_{z e}=\frac{31,5 d}{15+a_{g}} \\
d_{v}=0,9 \cdot d\end{array}$ \\
\hline 16. & $\begin{array}{c}\text { Jang i in. } \\
\text { (2012) } \\
{[23]}\end{array}$ & $\begin{array}{l}V_{c}=\beta_{f} \cdot \frac{1}{6} \cdot \sqrt{f_{c}} \cdot b_{w} \cdot d \\
\text { gdzie: } \\
\beta_{f}=0,716+0,466 \cdot \frac{E_{f}}{E_{s}}-0,095 \cdot \frac{a}{d}+32,101 \cdot \rho_{f}\end{array}$ \\
\hline
\end{tabular}


Tabela 1 (cd.). Procedury obliczeniowe nośności na ścinanie elementów betonowych zbrojonych prętami FRP będące modyfikacją metod stosowanych w konstrukcjach żelbetowych

Table 1 (cont.). The shear prediction models of FRP reinforced concrete members, which are modification of design equations for the steel reinforced construction

\begin{tabular}{|c|c|c|}
\hline Lp. & Procedura & Wzór \\
\hline 17. & $\begin{array}{c}\text { Lignola i in. } \\
(2012) \\
{[30]}\end{array}$ & $\begin{array}{l}V_{c}=c \cdot\left(\frac{E_{f}}{E_{s}}\right)^{n} \cdot C_{R d, c} \cdot k \cdot\left(100 \rho_{f} \cdot f_{c}\right)^{\frac{1}{3}} \cdot b_{w} d \\
\text { gdzie: } \\
C_{R d, c}= \begin{cases}0,18 \text { dla } \quad \text { betonu_zwyklego } \\
0,12 \text { dla } \quad \text { betonu_lekkiego }\end{cases} \\
k=1+\sqrt{\frac{200}{d[\mathrm{~mm}]}} \leq 2,0 \\
\text { Zaproponowano: } \\
c=1,65 \text { i } n=0,6\end{array}$ \\
\hline 18. & $\begin{array}{c}\text { Kurth (2012) } \\
{[\text { [27] }}\end{array}$ & $\begin{array}{l}V_{c}=\beta \cdot \frac{1}{413} \cdot \kappa \cdot\left(100 \cdot \rho_{f} \cdot E_{f} \cdot f_{c}\right)^{1 / 3} \cdot b_{w} d \\
\text { gdzie: } \\
\beta=3 \frac{d}{a} \\
\kappa=1+\sqrt{\frac{200}{d[m m]}}\end{array}$ \\
\hline 19. & $\begin{array}{c}\text { Yousif (2015) } \\
{[48]}\end{array}$ & $\begin{array}{l}V_{c}=0,29 \mu \rho_{f}^{\frac{3}{8}} b_{w}\left(\frac{E_{f}}{E_{s}}\right)^{\frac{1}{3}}\left(1+\frac{d}{a}\right) \sqrt{\frac{f_{c} d_{0} d}{1+\frac{d_{0}}{d}}} \\
\text { gdzie: } \\
d_{0}=k\left(f_{c}\right)^{-\frac{2}{3}} \\
k=27,3 \sqrt{a_{g}} \text { gdy maksymalny wymiar kruszywa }\left(a_{g}\right) \\
\text { jest znany, w przeciwnym wypadku przyjmuje się } \\
k=120,7\left(a_{g}=17[\mathrm{~mm}]\right) \\
\text { Zalecane przyjęcie } \mu=10 \text { do celów projektowych. }\end{array}$ \\
\hline
\end{tabular}


Tabela 1 (cd.). Procedury obliczeniowe nośności na ścinanie elementów betonowych zbrojonych prętami FRP będące modyfikacją metod stosowanych w konstrukcjach żelbetowych

Table 1 (cont.). The shear prediction models of FRP reinforced concrete members, which are modification of design equations for the steel reinforced construction

\begin{tabular}{|c|c|c|}
\hline Lp. & Procedura & Wzór \\
\hline 20. & $\begin{array}{c}\text { Thomas } i \text { in. } \\
\text { (2016) } \\
{[42]}\end{array}$ & $\begin{array}{l}V_{c}=k_{1} \cdot k_{2} \cdot \tau_{c} \cdot b_{w} \cdot d \\
\text { gdzie: } \\
\tau_{c}=\frac{0,85 \sqrt{0,8 f_{c}}(\sqrt{1+5 \beta}-1)}{6 \beta} \\
\beta=\frac{0,8 f_{c}^{*}}{p_{t}}>1,0 \\
f_{c}^{*}=1,25 f_{c} \\
k_{1}=\left\{\begin{array}{ccc}2,5 d / a+0,12 & g d y & a / d \leq 2,5 \\
1,0 & g d y & a / d \geq 2,5\end{array}\right. \\
k_{2}=\left\{\begin{array}{ccc}1,0 & g d y & d \leq 300 \mathrm{~mm} \\
\frac{750}{450+d} & g d y & d>300 \mathrm{~mm}\end{array}\right. \\
p_{t}=\rho_{f} \frac{E_{f}}{E_{s}}\end{array}$ \\
\hline
\end{tabular}

\subsection{Procedury będące modyfikacją metod stosowanych w elementach zbrojonych prętami FRP}

Drugą grupę procedur stanowią modyfikacje istniejących wzorów na ścinanie elementów betonowych ze zbrojeniem kompozytowym, wykonane w celu uzyskania jak najlepszej zgodności z wynikami badaniami eksperymentalnymi (tabela 2). W pracy [14] zaproponowano optymalizację wzoru z amerykańskich wytycznych z 2003 roku [2] polegającą na zmianie wpływu stosunku sztywności zbrojenia kompozytowego i stalowego (poz. 1, tabela 2). Nową zależność określono na podstawie wyników badań eksperymentalnych, w których ustalono, że nośność na ścianie belek zbrojonych prętami kompozytowymi w stosunku do belek zbrojonych stalą jest proporcjonalna do pierwiastka sześciennego z ilorazu osiowej sztywności zbrojenia FRP i stalowego $\left(\sqrt[3]{\rho_{f} E_{f} / \rho_{s} E_{s}}\right)$. Modyfikację wzoru wg kanadyjskiej normy z 2002 roku [7] przedstawiono w publikacjach [37] (poz. 2, tabela 2), [38] (poz. 3, tabela 2) oraz końcowo w kanadyjskiej normie z 2012 roku [8] (poz. 4, tabela 2). Zmiany polegały między innymi na wyeliminowaniu zaobserwowanych sprzeczności w obliczeniach wg wzoru normy [7], 
m.in. zerowa nośność na ścinanie przekrojów betonowych bez zbrojenia lub nieracjonalnie małe wartości nośności dla elementów z małym stopniem zbrojenia. Ponadto w nowych formułach ujęto wpływy niektórych parametrów na nośność na ścinanie na podstawie innych procedur: np. przyjęto wpływ momentu zginającego $\mathrm{w}$ analizowanym przekroju jak w amerykańskiej normie [1] lub wpływ smukłości ścinania jak w pracy [50]. Modyfikacji istniejących procedur, mającej na celu uzyskanie jak najlepszej zgodności z wynikami badań, dokonano także w pracy [39] (poz. 5, tabela 2). Do prowadzonych analiz wykorzystano algorytmy genetyczne bazujące na procesach ewolucji biologicznej. Modyfikacji poddano m. in. wzór wg amerykańskich wytycznych z 2006 roku [3] oraz wzór wg kanadyjskiej normy z 2002 roku [7].

Podstawowym kierunkiem zmian, podjętych w wyniku porównania istniejących procedur obliczeniowych nośności na ścinanie elementów zbrojonych prętami kompozytowymi z wynikami badań doświadczalnych i zaobserwowanych rozbieżności, była przede wszystkim redukcja wpływu poszczególnych parametrów na nośność na ścinanie (np. przez zmianę wykładnika potęgi przy analizowanym parametrze). Warto zauważyć, że analiza i modyfikacje istniejących procedur wg normy kanadyjskiej [7] przyczyniły się do wprowadzenia nowego wzoru na nośność na ścinanie w kolejnej wersji normy [8].

Tabela 2. Procedury obliczeniowe nośności na ścinanie elementów betonowych zbrojonych prętami FRP będące modyfikacją metod stosowanych w elementach zbrojonych prętami FRP

Table 2. The shear prediction models of FRP reinforced concrete members, which are modification of design equations for the FRP reinforced construction

\begin{tabular}{|c|c|c|}
\hline Lp. & Procedura & Wzór \\
\hline 1. & $\begin{array}{c}\text { El-Sayed } i \text { in. } \\
(2005) \\
{[14]}\end{array}$ & $\begin{array}{l}V_{c, f}=\left(\frac{\rho_{f} E_{f}}{90 \beta_{1} f_{c}}\right)^{\frac{1}{3}}\left(\frac{\sqrt{f_{c}}}{6} b_{w} d\right) \leq \frac{\sqrt{f_{c}}}{6} b_{w} d \\
\text { gdzie: } \beta_{1 j} \text { jak w poz. } 8, \text { Tabela } 1\end{array}$ \\
\hline 2. & $\begin{array}{c}\text { Razaqpur i in. } \\
\text { (2006) } \\
{[37]}\end{array}$ & $\begin{array}{l}V_{c}=0,035 k_{m} k_{s} k_{a}\left(1+k_{r}\right) \sqrt{f_{c}} b_{w} d \leq 0,2 k_{s} \sqrt{f_{c}} b_{w} d \\
\text { gdzie: } \\
k_{m}=\left(\frac{V d}{M}\right)^{\frac{2}{3}} ; k_{r}=\left(E_{f} \rho_{f}\right)^{\frac{1}{3}} \\
k_{a}=\min \left\{\begin{array}{l}1,0 \\
\frac{2,5}{M / V d} ; k_{s}=\min \left\{\begin{array}{l}1,0 \\
\frac{750}{450+d}\end{array}\right.\end{array}\right.\end{array}$ \\
\hline
\end{tabular}


Tabela 2 (cd.). Procedury obliczeniowe nośności na ścinanie elementów betonowych zbrojonych prętami FRP będące modyfikacją metod stosowanych w elementach zbrojonych prętami FRP

Table 2 (cont.). The shear prediction models of FRP reinforced concrete members, which are modification of design equations for the FRP reinforced construction

\begin{tabular}{|c|c|c|}
\hline Lp. & Procedura & Wzór \\
\hline 3. & $\begin{array}{c}\text { Razaqpur i in. } \\
(2010) \\
{[38]}\end{array}$ & $\begin{array}{l}V_{c}=0,045 \cdot k_{m}{ }^{*} \cdot k_{a} \cdot k_{r}{ }^{*}\left(f_{c}\right)^{1 / 3} \cdot b_{w} \cdot d \\
\text { gdzie: } \\
k_{m}{ }^{*}=\left(\frac{V \cdot d}{M}\right)^{1 / 2} \\
k_{a}=\left\{\begin{array}{c}1,0 \quad d l a \\
\left(\frac{2,5}{M /(V d)}\right) \quad d l a \\
\left(\frac{M}{V \cdot d}\right) \geq 2,5\end{array}\right)<2,5 \\
k_{r}^{*}=1+\left(E_{f} \cdot \rho_{f}\right)^{1 / 3}\end{array}$ \\
\hline 4. & $\begin{array}{c}\text { CSA S806-12 } \\
{[8]}\end{array}$ & $\begin{array}{l}\mathrm{V}_{c}=0,05 \lambda k_{m} k_{r} \sqrt[3]{f_{c}} b_{w} d_{v} \\
\text { gdzie: } \\
k_{m}=\sqrt{\frac{V d}{M}} \leq 1,0 \\
k_{r}=1+\left(E_{f} \rho_{f}\right)^{\frac{1}{3}} \\
d_{v}=\max (0,9 d ; 0,72 h) \\
\text { oraz spełniony warunek: } \\
0,11 \sqrt{f_{c}} b_{w} d_{v} \leq V_{c} \leq_{v} 0,22 \sqrt{f_{c}} b_{w} d_{v} \\
f_{c}<60 M P a\end{array}$ \\
\hline
\end{tabular}


Tabela 2 (cd.). Procedury obliczeniowe nośności na ścinanie elementów betonowych zbrojonych prętami FRP będące modyfikacją metod stosowanych w elementach zbrojonych prętami FRP

Table 2 (cont.). The shear prediction models of FRP reinforced concrete members, which are modification of design equations for the FRP reinforced construction

\begin{tabular}{|c|c|c|}
\hline Lp. & Procedura & Wzór \\
\hline 5. & $\begin{array}{c}\text { Shahnewaz } \\
\text { i in. (2016) } \\
{[39]}\end{array}$ & $\begin{array}{l}\text { CSA 806-02: } \\
V_{c}=0,11 \cdot b_{w} \cdot d \cdot\left(\frac{d}{a}\right)^{0.4} f_{c}^{0.13}\left(\rho_{f} E_{f}\right)^{0,33} \\
\text { lub } \\
V_{c}=0,12 \cdot b_{w} \cdot d \cdot\left(\frac{d}{a}\right)^{0.83} f_{c}^{0.3}\left(\rho_{f} E_{f}\right)^{0,3} \\
\text { ACI 440.1R-06: } \\
V_{c}=1,75 \cdot f_{c}^{0,28} \cdot b_{w} \cdot d \cdot k \\
\text { gdzie: } \\
k=\sqrt{2 \rho_{f} n_{f}+\left(\rho_{f} n_{f}\right)^{2}}-\rho_{f} n_{f} \\
n_{f}=\frac{E_{f}}{E_{c}}\end{array}$ \\
\hline
\end{tabular}

\subsection{Procedury opracowane na podstawie wyników badań eksperymentalnych oraz z wykorzystaniem specjalistycznych analiz}

Trzecią grupę procedur obliczeniowych dotyczących elementów betonowych zbrojonych prętami kompozytowymi FRP stanowią wzory bazujące na wynikach badań eksperymentalnych elementów ścinanych niewymagających zbrojenia poprzecznego oraz na wynikach analiz zebranych wyników badań za pomocą specjalistycznych narzędzi analitycznych i numerycznych (tabela 3 ). W przeglądzie pominięto niektóre wzory, które autorzy uznali za niepraktyczne z projektowego punktu widzenia, np. podane w pracach [16], [29], [35].

W pracy [44] podano metodę obliczania nośności na ścinanie elementów betonowych zbrojonych prętami FRP, która została opracowana w oparciu o wyniki badań eksperymentalnych (poz. 1, tabela 3). Zaproponowany model odnosi się do statycznie obciążonych elementów o smukłości ścinania $a / d>2,7$ i został zaadaptowany do amerykańskich wytycznych [3], [4]. W pracy [5] na podstawie badań ustalono związek pomiędzy obciążeniem rysującym (moment krytyczny) a nośnością na ścinanie elementów zbrojonych podłużnie prętami kompozytowymi. Następnie uwzględniono wpływ smukłości ścinania, modułu i stopnia zbrojenia kompozytowego oraz wysokości użytecznej przekroju przy 
wykorzystaniu analizy regresji wyników badań własnych i obcych (poz. 2, tabela 3). W pracy [31] zaproponowano prosty model obliczeniowy bazujący na wynikach badań obcych na ścinanie belek betonowych zbrojonych prętami FRP (poz. 4, tabela 3). Jako główne założenie modelu obliczeniowego przyjęto, że tuż przed zniszczeniem elementu siła poprzeczna jest przenoszona głównie przez niezarysowaną część przekroju w strefie ściskanej. W związku z tym pozostałe mechanizmy przenoszące siłę ścinającą są pomijane, a wzór wyznacza niższą wartość niż rzeczywista nośność na ścinanie. Kolejno w pracy [45] zaproponowano model bazujący na wynikach badań obcych na ścinanie belek betonowych zbrojonych prętami FRP (poz. 5, tabela 3). Wyznaczenie nośności na ścinanie opiera się na określeniu średnich wartości naprężeń ścinających w strefie ściskanej przekroju (jako funkcji wytrzymałości betonu na rozciąganie). W analizach założono kąt zarysowania elementu wynoszący $45^{\circ}$. Na podstawie badań zaobserwowano, że jeżeli kąt zarysowania jest mniejszy niż założony to nośność na ścinanie maleje. Zjawisko to uwzględniono poprzez wpływ smukłości ścinania $(a / d)$. Wpływ właściwości kompozytowego zbrojenia podłużnego określono poprzez zastosowanie współczynnika uwzględniającego stosunek modułów sztywności zbrojenia FRP i stali oraz stopień zbrojenia elementu.

Wykorzystując programowanie genetyczne i bazę wyników badań obcych w pracy [25] zaproponowano wzór na określenie nośności na ścinanie. Metoda analizy opiera się na uogólnionych algorytmach genetycznych bazujących na zasadach ewolucji biologicznej i dziedziczności (np. mutacje, wymiana materiału genetycznego) i polega na zdefiniowaniu problemu, którego rozpoznanie i rozwiązanie następuje w sposób zautomatyzowany przy wykorzystaniu programu komputerowego. W przeprowadzonej analizie uwzględniono sześć parametrów: wytrzymałość betonu na ściskanie, szerokość i wysokość użyteczną przekroju, smukłość ścinania, stopień zbrojenia i stosunek modułów sztywności zbrojenia kompozytowego i stalowego. Otrzymany wzór ma zastosowanie w przypadku elementów o smukłości ścinania $a / d>2,5$ (poz. 3, tabela 3 ). W pracy [9] opracowano wzór na nośność na ścinanie wykorzystując metodę regresji wielokrotnej. W analizach uwzględniono następujące parametry: wytrzymałość betonu na ściskanie, szerokość i wysokość użyteczna przekroju, smukłość ścinania, stopień zbrojenia i moduł sprężystości zbrojenia FRP (poz. 6, tabela 3). Określono wstępny model statystyczny, w którym każdemu z analizowanych parametrów przypisano współczynniki stanowiące mnożnik i wykładnik danego parametru. W analizach pominięto interakcję poszczególnych parametrów. Wykorzystując regresję wielokrotną bazującą na danych z eksperymentalnych badań obcych wyznaczono wartości współczynników określających wpływ danego parametru. W pracy [35] opracowano wzór na ścinanie stosując systemy rozmyte, opierające się na procesie mapowania założonych zmiennych wejściowych z danymi wyjściowymi przy wykorzystaniu logiki rozmytej. Na podstawie bazy danych badań obcych uwzględniając wpływ parametrów: wytrzymałość betonu na ściskanie, szerokość i wysokość użyteczna przekroju, smukłość ścinania, sto- 
pień zbrojenia i moduł sprężystości zbrojenia FRP, zaproponowano nowy model obliczeniowy. Otrzymanego wzoru nie przytoczono w artykule ze względu na jego duży stopień skomplikowania. Kolejno w pracy [29] do określenia nośności na ścinanie wykorzystano sztuczne sieci neuronowe, dzięki którym możliwe jest sklasyfikowanie danych oraz określenie relacji naśladujący działanie biologicznych struktur mózgowych pomiędzy założonymi danymi wejściowymi i wyjściowymi. Wykorzystując sieci neuronowe na podstawie bazy danych dostępnych w literaturze, uwzględniając wpływ parametrów: wytrzymałość betonu na ściskanie, szerokość i wysokość użyteczna przekroju, smukłość ścinania, stopień zbrojenia i moduł sprężystości zbrojenia FRP, opracowano model obliczeniowy, którego podobnie jak w poprzednim przypadku nie przytoczono $\mathrm{w}$ zestawieniu w tabeli 3 z tych samych powodów. W końcu w pracy [16] przedstawiono propozycję modelu obliczeniowego $\mathrm{z}$ wykorzystaniem metod programowania w oparciu o biogeografię. Programowanie w oparciu o biogeografię jest matematycznym modelem opisującym relację pomiędzy danymi wejściowymi i wyjściowymi w oparciu o opis sposób rozmieszczenia gatunków roślin i zwierząt (m.in. migracje, powstawanie i wymieranie gatunków). W analizach uwzględniono następujące parametry z eksperymentalnych badań obcych: wytrzymałość betonu na ściskanie, szerokość i wysokość użyteczna przekroju, smukłość ścinania, stopień zbrojenia i moduł sprężystości zbrojenia FRP. Otrzymanego wzoru nie przytoczono ze względu na jego duży stopień skomplikowania $[17,28]$.

Tabela 3. Procedury obliczeniowe nośności na ścinanie elementów betonowych zbrojonych prętami FRP opracowane na podstawie wyników badań eksperymentalnych oraz z wykorzystaniem specjalistycznych analiz

Table 3. The shear prediction models of FRP reinforced concrete members, which were developed based on experiment database and advanced calculation tools

\begin{tabular}{|c|c|c|}
\hline Lp. & Procedura & Wzór \\
\hline 1. & $\begin{array}{c}\text { Tureyen i in. } \\
(2003)[44] \\
(A C I \text { 440.1 R-06 } \\
{[3],} \\
\text { ACI 440.1R-15 } \\
[4])\end{array}$ & $\begin{array}{l}V_{c}=\frac{2}{5} k \sqrt{f_{c}} b_{w} d \\
\text { gdzie: } \\
k=\sqrt{2 \rho_{f} n_{f}+\left(\rho_{f} n_{f}\right)^{2}}-\rho_{f} n_{f} ; n_{f}=\frac{E_{f}}{E_{c}}\end{array}$ \\
\hline 2. & $\underset{[5]}{\operatorname{Alam}(2010)}$ & $\begin{array}{l}V_{c}=\frac{0,2 \cdot \lambda}{(a / d)^{2 / 3}}\left(\frac{\rho_{f} E_{f}}{d}\right)^{1 / 3} \sqrt{f_{c}} \cdot b_{w} \cdot d \\
\text { przy czym: } \\
\frac{0,1 \cdot \lambda}{a / d} \sqrt{f_{c}} \cdot b_{w} \cdot d \leq V_{c} \leq 0,2 \cdot \lambda \sqrt{f_{c}} \cdot b_{w} \cdot d\end{array}$ \\
\hline
\end{tabular}


Tabela 3 (cd.). Procedury obliczeniowe nośności na ścinanie elementów betonowych zbrojonych prętami FRP opracowane na podstawie wyników badań eksperymentalnych oraz z wykorzystaniem specjalistycznych analiz

Table 3 (cont.). The shear prediction models of FRP reinforced concrete members, which were developed based on experiment database and advanced calculation tools

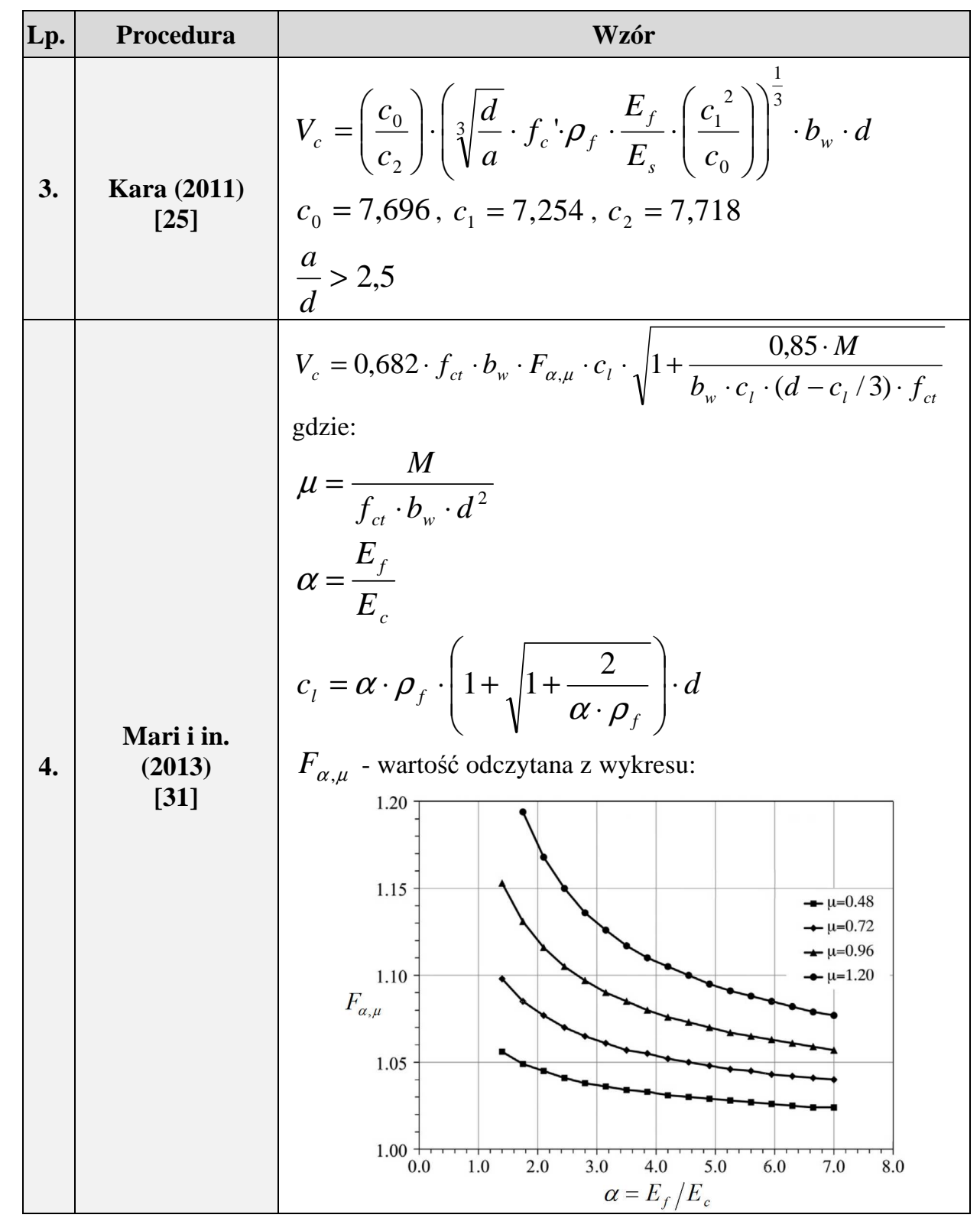


Tabela 3 (cd.). Procedury obliczeniowe nośności na ścinanie elementów betonowych zbrojonych prętami FRP opracowane na podstawie wyników badań eksperymentalnych oraz z wykorzystaniem specjalistycznych analiz

Table 3 (cont.). The shear prediction models of FRP reinforced concrete members, which were developed based on experiment database and advanced calculation tools

\begin{tabular}{|c|c|l|}
\hline Lp. & \multicolumn{1}{|c|}{ Procedura } & \multicolumn{1}{c|}{ Wzór } \\
\hline & & $V_{c}=\frac{\varphi_{c 2} \cdot \varphi_{f} \cdot f_{c t} \cdot b_{w} \cdot d^{2}}{a} \geq \varphi_{c 3} \cdot \varphi_{f} \cdot f_{c t} \cdot b_{w} \cdot d$ \\
5. & $\begin{array}{c}\text { Valivonis i in. } \\
\text { (2015) } \\
\text { [45] }\end{array}$ & $\varphi_{f}=0,4\left(\frac{E_{f}}{E_{s}}\right)^{\rho_{f}}$ \\
& $a \leq \frac{\varphi_{c 4}}{\varphi_{c 3}} d$ \\
& $\begin{array}{c}\text { Chowdhury } \\
\text { i in. (2015) } \\
\text { [9] }\end{array}$ & $\varphi_{c 2}=2,0 ; \varphi_{c 3}=0,45 ; \varphi_{c 4}=1,5$ \\
& & $+2,63 \cdot \sqrt{E_{f}}-37,571 \cdot\left(\frac{a}{d}\right)^{2 / 3}+12,966 \cdot \rho_{f}$ \\
\hline
\end{tabular}

Modele opracowane na podstawie analizy wyników badań opierały się głównie na opisie przenoszenia siły poprzecznej przez strefę ściskaną betonu niezarysowanego lub analizie momentu krytycznego, tj. obciążenia powodującego zarysowanie przekroju. W przypadku procedur opracowanych z wykorzystaniem specjalistycznych narzędzi zwykle zakładano parametry uwzględniane w większości wzorów dotyczących elementów zbrojonych prętami kompozytowymi i w sposób zautomatyzowany ustalano stopień i sposób ich wpływu na nośność na ścinanie w oparciu o bazę danych wejściowych i wyjściowych. Warto jednak zauważyć, że pomimo wykazania dobrej zgodności zaproponowanych wzorów z wynikami badań doświadczalnych, mają one często skomplikowaną, a tym samym niepraktyczną w zastosowaniu formułę.

\section{Wpływ głównych parametrów przekroju poprzecznego elementu na jego nośność na ścinanie}

$\mathrm{Na}$ podstawie analizy przedstawionych procedur obliczeniowych można wyróżnić sześć podstawowych parametrów przekroju poprzecznego uwzględnianych we wzorach na nośność na ścinanie elementów ze zbrojeniem kompozytowym niewymagających zbrojenia na ścinanie. Są to: wysokość użyteczna przekroju $(d)$, szerokość elementu $\left(b_{w}\right)$, smukłość ścinania $(a / d)$, stopień zbrojenia elementu $\left(\rho_{f}\right)$, moduł sprężystości zbrojenia podłużnego $\left(E_{f}\right)$ oraz wytrzyma- 
łość betonu na ściskanie $\left(f_{c}\right)$. W tabeli 4 pokazano, które z tych parametrów zostały uwzględnione w poszczególnych procedurach obliczeniowych.

Tabela 4. Uwzględnienie poszczególnych parametrów przekroju na jego nośność na ścinanie $\mathrm{w}$ danych procedurach obliczeniowych

Table 4. Parameters affecting shear capacity considered in presented models and codes

\begin{tabular}{|c|c|c|c|c|c|c|c|}
\hline \multirow[t]{2}{*}{$\mathrm{Lp}$} & \multirow{2}{*}{ Procedura obliczeniowa } & \multicolumn{6}{|c|}{ Parametr przekroju } \\
\hline & & $\mathrm{b}$ & $\mathrm{d}$ & $\mathrm{a} / \mathrm{d}$ & $f_{c}$ & $\mathrm{E}_{\mathrm{f}}$ & $\rho_{\mathrm{f}}$ \\
\hline \multicolumn{8}{|c|}{ Grupa I -Modyfikacje wzorów dotyczących konstrukcji żelbetowych } \\
\hline 1. & Tottori i in. (1993) [43] & + & + & + & + & + & + \\
\hline 2. & JSCE-97 (1997)[24] & + & + & - & + & + & + \\
\hline 3. & Michaluk i in.(1998) [32] & + & + & - & + & + & - \\
\hline 4. & IStructE (1999)[21] & + & + & - & + & + & + \\
\hline 5. & Deitz i in.(2001) [12] & + & + & - & + & + & - \\
\hline 6. & ISIS $(2001,2007)[22]$ & + & + & - & + & + & - \\
\hline 7. & CSA-S806-02[7] & + & + & + & + & + & + \\
\hline 8. & ACI 440.1R-03[2] & + & + & - & + & + & + \\
\hline 9. & ECP 208 (2005)[13] & + & + & - & + & + & + \\
\hline 10. & Wegian i in. (2005) [46] & + & + & + & + & + & + \\
\hline \multirow{3}{*}{11.} & Guadagnini i in. (2006) [18] (EC2) & + & + & - & + & + & + \\
\hline & Guadagnini i in. (2006) [18] (BISE) & + & + & - & + & + & - \\
\hline & Guadagnini i in. (2006) [18] (ACI) & + & + & - & + & + & - \\
\hline 12. & CNR DT $203-2006$ [11] & + & + & - & + & + & + \\
\hline 13. & Nehdi i in. (2007) [36] & + & + & + & + & + & + \\
\hline 14. & CSA S6-06 [6] & + & + & + & + & + & - \\
\hline 15. & Hoult $\mathrm{i}$ in. (2008) [20] & + & + & + & + & + & - \\
\hline 16. & Jang i in. (2008) [23] & + & + & + & + & + & + \\
\hline 17. & Lignola i in. (2012)[30] & + & + & - & + & + & + \\
\hline 18. & Kurth (2012)[27] & + & + & + & + & + & + \\
\hline 19. & Yousif (2015)[48] & + & + & + & + & + & + \\
\hline 20. & Thomas i in. (2016)[42] & + & + & + & + & + & + \\
\hline \multicolumn{8}{|c|}{ Grupa II - Modyfikacje wzorów dotyczących konstrukcji zbrojonych FRP } \\
\hline 1. & El-Sayed i in. (2005) [14] & + & + & - & + & + & + \\
\hline 2. & Razaqpur i in. (2006) [37] & + & + & + & + & + & + \\
\hline 3. & Razaqpur i in. (2010) [38] & + & + & + & + & + & + \\
\hline 4. & CSA S806-12 [8] & + & + & + & + & + & + \\
\hline \multirow{2}{*}{5.} & Shahnewaz i in. (2016) [39] (CSA) & + & + & + & + & + & + \\
\hline & Shahnewaz i in. (2016) [39] (ACI) & + & + & - & + & + & + \\
\hline \multicolumn{8}{|c|}{ Grupa III - Modele obliczeniowe powstałe na podstawie badań } \\
\hline 1. & $\begin{array}{c}\text { Tureyen i in. (2003) [44] } \\
\text { (ACI 440.1R-06 [3], } \\
\text { ACI 440.1R-15 [4]) }\end{array}$ & + & + & - & + & + & + \\
\hline 2. & Alam (2010) [5] & + & + & + & + & + & + \\
\hline 3. & Kara (2011) [25] & + & + & + & + & + & + \\
\hline 4. & Mari i in. (2013) [31] & + & + & - & + & + & + \\
\hline 5. & Valivonis i in. (2015) [45] & + & + & + & + & + & + \\
\hline 6. & Chowdhury $\mathrm{i}$ in. (2015)[9] & + & + & + & + & + & + \\
\hline
\end{tabular}


Poniżej dokonano krótkiej analizy wpływu poszczególnych parametrów na nośność na ścinanie elementu zbrojonego prętami FRP.

\subsection{Geometria elementu: wysokość użyteczna $(d)$, smukłość ścinania $(a / d)$, szerokość $\left(b_{w}\right)$}

Wzrost wysokości użytecznej przekroju (d) powoduje wzrost kąta nachylenia rysy, a tym samym przyczynia się do zmniejszenia głównych naprężeń rozciągających w strefie ścinania. Zatem wraz ze wzrostem wysokości użytecznej przekroju wzrasta nośność przekroju na ścinanie. Wszystkie przedstawione procedury zakładają wprost proporcjonalną zależność pomiędzy wysokością użyteczną przekroju a nośnością na ścinanie.

W zależności od wartości smukłości ścinania betonowe elementy zbrojone można podzielić na dwie grupy: tzw. belki smukłe, w których stosunek $a / d \geq 2,5$ oraz belki pozostałe, tj. tzw. belki krótkie i belki ściany. Wraz ze wzrostem stosunku (a/d) maleje nośność na ścinanie elementu zbrojonego prętami FRP, jednak charakter wpływu tego parametru może być liniowy lub nie. Liniowy wpływ smukłości ścinania uwzględniono w pracach [23], [27], [42], [43], [48]. W pozostałych przypadkach ten parametr jest uwzględniany w postaci potęgowej o wykładniku: $n=(-1 / 3)$ w normie [7] i pracach [36] i [46], $n=(-1 / 2)$ w normie [8] i w pracy [38] oraz $n=(-2 / 3)$ w pracy [37]. Często zależność ta jest także funkcją siły poprzecznej i momentu zginającego, działających w rozpatrywanym przekroju, m.in. w normach [7], [8] lub pracach [20], [37], [38].

Wszystkie przedstawione procedury obliczeniowe uwzględniają wprost proporcjonalny wpływ szerokości elementu $(b)$ na nośność na ścinanie.

\subsection{Stopień zbrojenia podłużnego}

Wraz ze wzrostem stopnia zbrojenia, maleje wysokość i szerokość rysy. Redukcja wysokości rysy powoduje wzrost wytrzymałości na ścinanie przenoszonej przez niezarysowaną cześć przekroju, a redukcja rozwartości rysy powoduje wzrost nośności na ścinanie przenoszonej w wyniku zakleszczania się kruszywa (ang. aggragate locking) oraz w wyniku tzw. efektu klockującego (ang. dowel action). W większości wzorów obliczeniowych zależność nośności na ścinanie od stopnia zbrojenia elementu wyrażana jest wykładniczo z potęgą $n=1 / 3$. Inaczej stanowią procedury wg wytycznych [2], [3], [11], normy [13] oraz opisane w pracach [23], [31] i [48], gdzie zastosowano stosowano zależność liniową. Natomiast w pracy [45] uwzględniono wpływ stopnia zbrojenia jako wykładnik potęgi o podstawie będącej stosunkiem modułu sprężystości zbrojenia kompozytowego i stalowego $n=E_{f} / E_{s}$. 


\subsection{Moduł sprężystości zbrojenia podłużnego}

Wpływ modułu sprężystości zbrojenia podłużnego uwzględniano pośrednio za pomocą tzw. sztywności zbrojenia. Sztywność zbrojenia podłużnego jest określana za pomocą iloczynu stopnia zbrojenia podłużnego i modułu sprężystości kompozytu $\left(\rho_{f} E_{f}\right)$. Wraz ze wzrostem sztywności zbrojenia wzrasta nośność na ścinanie elementu. Mniejsza sztywność zbrojenia skutkuje zwiększeniem naprężeń rozciągających $\mathrm{w}$ zbrojeniu, co $\mathrm{z}$ kolei powoduje zmniejszenie strefy ściskanej betonu i prowadzi do powstawania rys o większej rozwartości, a ostatecznie do zmniejszenia nośności elementu na ścinanie. W wielu procedurach obliczeniowych odwoływano się również do stosunku modułu sprężystości zbrojenia kompozytowego i stali $\left(E_{f} / E_{s}\right)$. Między innymi w wytycznych [2], normie [13] i pracach [12], [23] i [32] przyjęto liniową zależność pomiędzy modułem sprężystości zbrojenia FRP, a nośnością na ścinanie. Jednak w większości procedur stosowano zależność wykładniczą o potędze $n=1 / 3$ ( $\mathrm{m}$. in. w normie [7], wytycznych [21], [24], pracach [14], [27], [46], [48]) lub o potędze $n=1 / 2$ (m. in. w wytycznych [11] i [22]).

\subsection{Parametry wytrzymałościowe betonu}

Zniszczenie elementu betonowego w wyniku ścinania następuje równocześnie lub tuż po pojawieniu się rysy ukośnej. Rysa pojawia się w wyniku przekroczenia wytrzymałości na rozciąganie betonu w kierunku głównych naprężeń rozciągających. W większości procedur obliczeniowych wytrzymałość betonu na rozciąganie jest rozważana jako funkcja wytrzymałości na ściskanie, najczęściej stosowano zależność wykładniczą o potędze $n=1 / 3, \mathrm{~m}$. in. w normie [7], wytycznych [21], [24], pracach [25], [27], [36] lub o potędze $n=1 / 2, \mathrm{~m}$. in. w normie [13], wytycznych [3], [22] i pracach [20], [37], [42], [48].Warto również zauważyć, że bezpośredni wpływ modułu sprężystości betonu uwzględniono jedynie w procedurze wg amerykańskich wytycznych [3] i [4] oraz w pracy [31].

\section{Ilościowe porównanie nośności na ścinanie wg wybranych procedur obliczeniowych}

W celu przedstawienia ilościowego różnic $\mathrm{w}$ wartościach nośności na ścinanie elementów zbrojonych prętami kompozytowymi bez zbrojenia poprzecznego według różnych procedur obliczeniowych, wykonano obliczenia dla przykładowego zestawu danych wyjściowych (rys. 2). Dla uproszczenia przyjęto zależność $M=V \cdot a$ pomiędzy siłami wewnętrznymi w analizowanym przekroju. 
Schemat obciażenia:

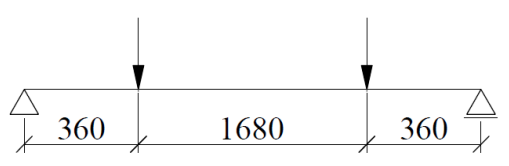

\section{Przekrój poprzeczny:}

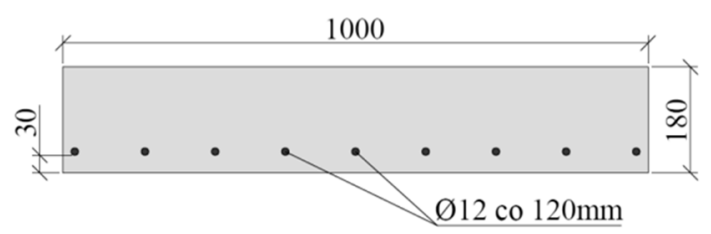

\section{Beton:}

$$
\begin{gathered}
f_{c}=40,8 \mathrm{MPa} \\
f_{c t}=3,22 \mathrm{MPa} \\
E_{c}=24,7 \mathrm{GPa} \\
a_{g}=20 \mathrm{~mm}
\end{gathered}
$$

\section{Zbrojenie:}

$$
\begin{gathered}
E_{f}=50 \mathrm{GPa} \\
E_{s}=200 \mathrm{GPa}
\end{gathered}
$$

Rys. 2. Geometria i parametry materiałowe płyty betonowej przyjętej do analizy porównawczej (wymiary w mm)

Fig. 2. Geometry and materials characteristic of slab for comparative analysis (dimension in $\mathrm{mm}$ )

Porównanie ograniczono jedynie do procedur zawartych w najnowszych wersjach analizowanych norm i wytycznych. Na rys. 3 przedstawiono ilościowe porównanie wartości nośności na ścinanie wg norm: [4], [8], [13] i wytycznych: [11], [21], [22], [24] oraz metody MCFT opisanej w pracy [20].

Można zauważyć znaczące rozbieżności wyników uzyskanych według poszczególnych procedur. Najmniejszą wartość uzyskano dla wzoru wg normy egipskiej [13], zaś największą dla procedury wg wytycznych włoskich [11]. Warto zauważyć, że wartości skrajne różnią się od siebie blisko 9-krotnie. Rażąco mała wartość nośności na ścinanie wg normy [13] wynika z przyjęcia stosunkowo wysokiego porównawczego stopnia zbrojenia stalowego - jest to wartość maksymalna, podczas gdy w przypadku podobnej modyfikacji wzoru dotyczącego konstrukcji żelbetowej według wytycznych amerykańskich z 2003 roku [2] zalecane jest jako porównawcze przyjęcie połowy maksymalnego stopnia zbrojenia stalowego. Wyraźnie odbiegającą wartość od pozostałych uzyskano także dla wzoru wg wytycznych amerykańskich [4]. Nośności na ścianie według pozostałych analizowanych procedur różnią się między sobą o około $15 \%$. Warto jednak zauważyć, że w publikacji [10] na podstawie bazy danych składającej się z wyników badań dla 157 belek lub płyt wykazano m. in., że wytyczne włoskie [11] przeszacowują nośność na ścinanie, natomiast wytyczne amerykańskie [4] określają zbyt małą wartość w odniesieniu do wyników badań eksperymentalnych. W przypadku analizy procedury wg wytycznych włoskich [11] uzyskano nawet 3-krotnie wyższą wartość nośności obliczonej niż wartość eksperymentalna, natomiast w przypadku amerykańskich wytycznych [4] nośność obliczona była nawet ponad 5-krotnie niższą niż wartość uzyskana z badań doświadczalnych [10]. 


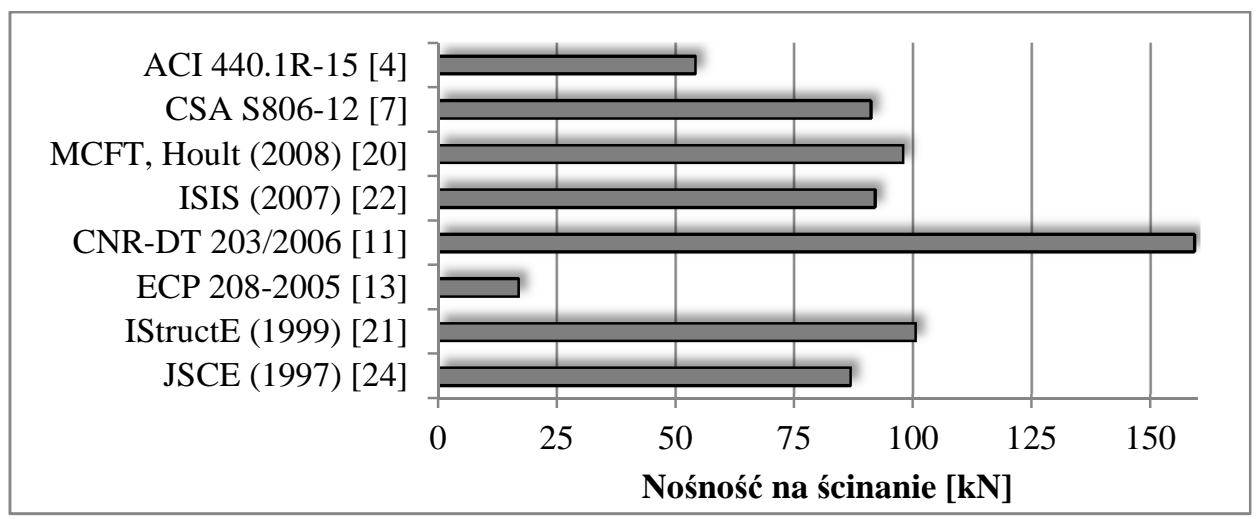

Rys. 3. Porównanie nośności na ścinanie elementu zbrojonego prętami FRP wyznaczonych wybranymi procedurami obliczeniowymi

Fig. 3. Comparison of shear capacity of concrete member reinforced with FRP bars computed using different shear design procedures

Warto zauważyć, że tylko nieliczne procedury (np. wg norm [7], [8], wytycznych [22] i pracy [5]) pozwalają na uwzględnienie betonu lekkiego poprzez odpowiedni współczynnik redukcyjny, tak jak ma to miejsce w przypadku norm dotyczących konstrukcji żelbetowych m. in. [1] i [15]. Próbę weryfikacji tych procedur autorzy przeprowadzili $\mathrm{w}$ oparciu o badania własne opisane $\mathrm{w}$ pracy [47]. Badaniu poddano płytę z betonu lekkiego na bazie kruszywa Pollytag o grubości $18 \mathrm{~cm}$, zbrojoną prętami GFRP o średnicy $12 \mathrm{~mm}$. Płyta miała schemat dwuprzęsłowy o rozpiętości przęsła $2,4 \mathrm{~m}$ i uległa zniszczeniu w wyniku ścinania, a jej nośność na ścinanie wynosiła 148,8 kN/m (rys. 4).

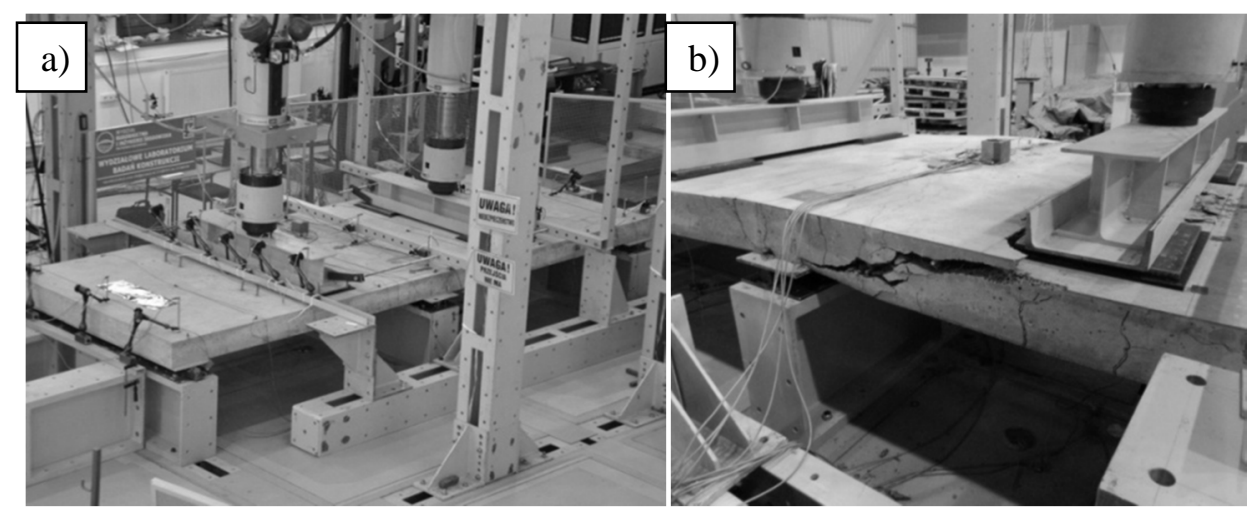

Rys. 4. Badania wytrzymałościowe płyty $\mathrm{z}$ betonu lekkiego zbrojonej prętami GFRP: (a) widok stanowiska badawczego; (b) postać zniszczenia na ścinanie [47].

Fig. 4. Structural testing of lightweight concrete slab reinforced with GFRP rebars: (a) view on slab under testing; (b) shear failure of slab [47]. 
Do analizy obliczeniowej przyjęto pasmo płyty o szerokości $1 \mathrm{~m}$, a wartość współczynnika $\lambda$ określającego wpływ zastosowania betonu lekkiego przyjęto jako 0,85 - frakcję drobną kruszywa stanowił wyłącznie piasek. Przyjęta wartość współczynnika $\lambda$ jest jednakowa w przypadku wszystkich analizowanych procedur. Zestawienie wyników analiz obliczeniowych i badań doświadczalnych przedstawiono na rys. 5 .

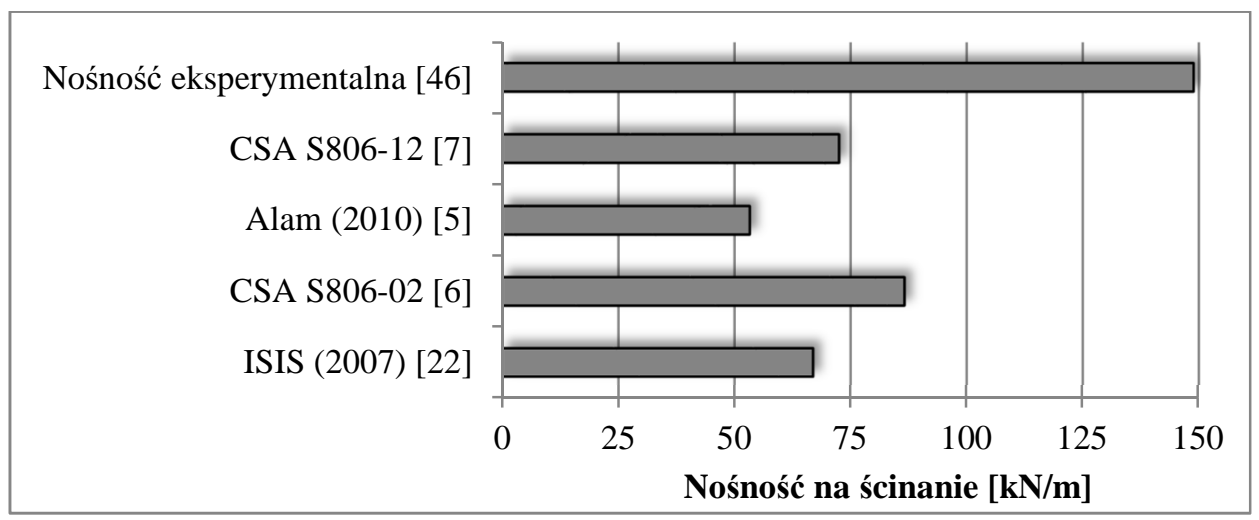

Rys. 5. Porównanie nośności na ścinanie płyty z betonu lekkiego uzyskanej eksperymentalnie oraz wybranymi procedurami obliczeniowymi

Fig. 5. Comparison of test result and shear capacity of lightweight concrete slab computed using several shear design procedures

Na rys. 5 można zaobserwować, że wszystkie wyznaczone obliczeniowo nośności są około dwu- lub trzykrotnie niższe niż wartość uzyskana eksperymentalnie. Warto również zauważyć, że wartości obliczone wg przyjętych procedur były mniejsze od wartości eksperymentalnej nośności nawet w przypadku nieuwzględniania wpływu zastosowania betonu lekkiego $(\lambda=1,0)$, podając tym samym w wątpliwość zasadność stosowania takiego współczynnika. Jednakże ze względu na bardzo mały zakres przeprowadzonych analiz w tym zakresie, w celu uogólnienia przedstawionych wniosków konieczne jest prowadzenie dalszych prac nad nośnością na ścinanie w przypadku zastosowania betonu lekkiego w elementach zbrojonych prętami kompozytowymi.

\section{Podsumowanie}

W przeciągu kilku ostatnich dekad, wiele ośrodków naukowych było zaangażowanych $\mathrm{w}$ prowadzenie badań i opracowywanie modeli obliczeniowych w celu zrozumienia i jak najlepszego opisu matematycznego zachowania się elementów betonowych zbrojonych podłużnie prętami kompozytowymi. Rezultatem prowadzonych badań i analiz są m.in. liczne wzory, metody i procedury 
obliczeniowe pozwalające na wyznaczenie nośności na ścinanie elementów betonowych ze zbrojeniem FRP. Przedstawione w pracy modele w sposób mniej lub bardziej dokładny opisują zjawisko ścinania w odniesieniu do wyników badań eksperymentalnych oraz reprezentują różny stopień złożoności obliczeniowej.

Na podstawie przeprowadzonej analizy dostępnych procedur obliczeniowych można wyróżnić sześć podstawowych parametrów uwzględnianych w modelach opisujących nośność na ścinanie elementów zbrojonych prętami FRP bez zbrojenia poprzecznego. Są to: wytrzymałość betonu na ściskanie, szerokość i wysokość użyteczna przekroju, smukłość ścinania, stopień zbrojenia i moduł sprężystości zbrojenia kompozytowego. W elementach betonowych bez zbrojenia poprzecznego ważną rolę $w$ przenoszeniu siły ścinającej ma także zjawisko zakleszczanie się kruszywa wzdłuż rysy ukośnej (ang. aggregate interlock). Zjawisko to może być uwzględnione w modelu poprzez wpływ maksymalnego wymiaru kruszywa w mieszance betonowej. Parametr ten uwzględniono jedynie $w$ dwóch analizowanych procedurach w pracach [20], [48]. Ponadto w żadnej procedurze nie uwzględniono parametrów mających wpływ na zarysowanie się elementu zginanego tj. wpływu przyczepności zbrojenia kompozytowego do betonu jak również liczby prętów i ich rozstawu. Wzorując się na normach dotyczących konstrukcji żelbetowych m. in. [1] i [15], których procedury pozwalają na uwzględnienie betonu lekkiego poprzez odpowiedni współczynnik redukcyjny w analogiczny sposób uwzględniono wpływ rodzaju zastosowanego betonu w wzorach wg norm [7], [8], wytycznych [22] i pracy [5]. Jednakże uwzględnianie w procedurach obliczeniowych wpływu tego parametru wymaga szerszych badań i analiz.

Określenie uniwersalnej metody szacowania nośności na ścinanie elementów betonowych zbrojonych prętami kompozytowymi jest trudne ze względu z jednej strony na złożoność opisu mechanizmów zniszczenia, zaś z drugiej strony ze względu na konieczność praktycznego zastosowania proponowanych procedur w projektowaniu - uzyskanie jak najprostszej ich formy. Biorąc pod uwagę znaczne różnice pomiędzy wartościami nośności na ścinanie wyznaczonych wg dostępnych procedur (rys. 2), jak również różny sposób uwzględniania poszczególnych parametrów, można stwierdzić, że zagadnienie ścinania elementów betonowych zbrojonych podłużnie prętami kompozytowymi wymaga dalszych badan i analiz, w szczególności w przypadku elementów wykonanych $\mathrm{z}$ betonu lekkiego.

\section{Literatura}

[1] ACI 318:2005 Building Code Requirements for Structural Concrete, American Concrete Institute, Farmington Hills, MI, 2005.

[2] ACI 440.1R-03 Guide for the Design and Construction of Concrete Reinforced with FRP Bar. American Concrete Institute, Farmington Hills, MI, 2003. 
[3] ACI 440.1R-06 Guide for the Design and Construction of Structural Concrete Reinforced with FRP Bars. ACI Committee 440, ACI Committee 440, American Concrete Institute, Farmington Hills, MI, 2006.

[4] ACI 440.1R-15 Guide for the design and construction of structural concrete reinforced with fiber-reinforced polymer (FRP) bars. ACI Committee 440, American Concrete Institute, Farmington Hills, MI, 2012.

[5] Alam M.S.: Influence of different parameters on shear strength of FRP reinforced concrete beams without web reinforcement, Ph.D. Thesis, Memorial University of Newfoundland, 2010.

[6] CAN/CSA S6-06 Canadian Highway Bridge Design Code(CHBDC), Canadian Standards Association, Rexdale, Ontario, Canada, 2006.

[7] CAN/CSAS806-02 Design and Construction of Building Components with FibreReinforced Polymers. CSA, Canadian Standards Association (CSA) International, Toronto, Canada, 2002.

[8] CAN/CSA S806-12 Design and Construction of Building Components with FiberReinforced Polymers. Canadian Standards Association, Mississauga, Ontario, Canada, 2012.

[9] Chowdhury M.A., Zahid Z.I., Islam M.M.: Simplified Shear Strength Prediction Model of FRP Reinforced Concrete Beam without Web Reinforcement. First International Conference on Advances in Civil Infrastructure and Construction Materials (CICM 2015), At MIST, Dhaka, Bangladesh, 2015.

[10] Chowdhury M., Ibna Zahid Z., Islam M.: Development of Shear Capacity Prediction Model for FRP-RC Beam without Web Reinforcement. Advances in Materials Science and Engineering, Volume 2016.

[11] CNR DT 203 - 2006 Recommendations for the Design, Realization and Control Of Structures In Concrete Reinforced with Fiber-reinforced Composite Bars. Rome, Italy: National Research Council, 2006.

[12] Deitz D.H., Harik I.E., Gersund H.: One-Way Slabs Reinforced with Glass Fiber Reinforced Polymer Reinforcing Bars,. In Proceedings, 4th International Symposium Fiber-Reinforced Polymer (FRP) Reinforcement for Concrete Structures, FRPRCS4, Farmington Hills, MI: American Concrete Institut, 1999.

[13] ECP 208:2005 Egyptian Code of Practice for Design Principles of the Use of Fiber Reinforced Polymers in Construction. Permanent Committee, Code No. 208, Cairo, Egypt, 2005.

[14] El-Sayed A., El-Salakawy E., Benmokrane B.: Shear strength of concrete beams reinforced with FRP bars: Design method. Proceedings of the 7th International Symposium on Fiber Reinforced Polymer Reinforcement for Concrete Structures FRPRCS-7, 2005.

[15] EN 1992-1-1:2004 Eurocode 2: Design of concrete structures - Part 1-1: General rules and rules for buildings. European Committee for Standardisation, Brussels, 2004.

[16] Golafshani E.M., Ashour A.: A feasibility study of BBP for predicting shear capacity of FRP reinforced concrete beams without stirrups. Advances in Engineering Software, 97, 2016.

[17] Gremel D., Koch R.: Holistic approach to reduce the costs of bridge decks using FRP rebar, http://www.ktc.uky.edu/ (dostęp: 16.01.2017 r.). 
[18] Guadagnini M., Pilakoutas K., Waldron P.: Shear resistance of FRP RC beams: Experimental study. Journal of Composites for Construction, 10 (6), 2006.

[19] Gurutzeaga M., Oller E., Ribas C., Cladera A., Mari A.: Influence of the longitudinal reinforcement on shear strength of one-way concrete slabs. Materials and Structures, vol. 48, no. 8, 2015.

[20] Hoult N. A., Sherwood E. G., Bentz E. C., Collins M. P.: Does the use of FRP reinforcement change the one-way shear behavior of reinforced concrete slabs?. Journal of Composites for Construction, vol. 12, no. 2, 2008.

[21] Institution of Structural Engineers (IStructE), Interim Guidance on the Design of Reinforced Concrete Structures Using Fibre Composite Reinforcement. IStructE, London, 1999.

[22] ISIS: Reinforcing Concrete Structures with Fibre Reinforced Polymers. Design Manual No. 3, Canadian Network of Centres of Excellence on Intelligent Sensing for Innovative Structures, Winnipeg, 2007.

[23] Jang H.S., Kim C.H.: Concrete Shear Strength of Normal and Lightweight Concrete Beams Reinforced with FRP Bars. Proceedings of The annual International Conference organized by the International Institute for Infrastructure, Renewal and Reconstruction (IIIRR) hosted by Kumamoto University will be held at Kumamoto, Japan, August 24-26, 2012.

[24] Japan Society of Civil Engineers (JSCE): Recommendation for design and construction of concrete structures using continuous fibre reinforcing materials. Research Committee on Continuous Fiber Reinforcing Materials, Japan Society of Civil Engineers, Tokyo, Japan, 1997.

[25] Kara I.F.: Prediction of shear strength of FRP-reinforced concrete beams without stirrups based on genetic programming. Advances in Engineering Software, 42, 2011.

[26] Knauff M.: Obliczanie konstrukcji żelbetowych według Eurokodu 2. Wydawnictwo Naukowe PWN, Warszawa 2012.

[27] Kotynia R., Kaszubska M.: Nośność na ścinanie belek betonowych zbrojonych prętami kompozytowymi bez zbrojenia poprzecznego w świetle badań obcych. Inżynieria i Budownictwo, Nr 12/2016.

[28] Kurth M., Hegger J.: Experimental and theoretical study on shear capacity of concrete beams with FRP reinforcement. In: Giorgio Monti (Hg.); 6th International Conference on FRP Composites in Civil Engineering (CICE 2012), Rom, Italien, 13.-15.06.2012.

[29] Lee S., Lee C.: Prediction of shear strength of FRP-reinforced concrete flexural members without stirrups using artificial neural networks. Engineering Structures, 61, 2014.

[30] Lignola G.P., Nardone F., Prota A., Manfredi G.: Assessment of Design Equation for The Shear Capacity of FRP-RC Members. Proceedings of 6th International Conference on Fiber Reinforced Polymer (FRP) Composites in Civil Engineering, 2012.

[31] Mari A., Cladera A., Oller E., Bairan J.: Shear design of FRP reinforced concrete beams without transverse reinforcement. Composites: Part B, 57, 2014.

[32] Michaluk R., Rizkalla S., Tadros G., Benmokrane B.: Flexural behavior of one-way concrete slabs reinforced by fiber reinforced plastic reinforcements. ACI Structural Journal, 95(3), 1998. 
[33] Mossakowski P.: Pręty z kompozytów polimerowych z włóknami do zbrojenia betonowych konstrukcji inżynierskich. Drogi i Mosty, nr 1/2006, s. 35-52.

[34] Nanni A., De Luca A., Zadeh H.J.: Reinforced Concrete with FRP Bars. Mechanics and Design. CRC Press, Taylor \& Francis Group, 2014.

[35] Nasrollahzadeh K., Basiri M.: Prediction of shear strength of FRP reinforced concrete beams using fuzzy inference system. Expert Systems with Applications, 41, 2014.

[36] Nehdi M., El Chabi H., Aly Said A.: Proposed shear design equations for FRP reinforced concrete beams based on genetic algorithms approach. Journal of Materials in Civil Engineering, 19 (12), 2007.

[37] Razaqpur A.G., Isgor O.B.: Proposed Shear Design Method for FRP Reinforced Concrete Members without Stirrups. ACI Structural Journal, 103(1), 2006.

[38] Razaqpur A.G., Spadea S.: Shear Strength of Reinforced Concrete Elements Brackets with FRP. In: Proceedings of AIAS, 39th National Congress of Italian Association of Stress Analysis, Calabria, Italy, 2010.

[39] Shahnewaz M., Machial R., Alam M.S., Rteil A.: Optimized shear design equation for slender concrete beams reinforced with FRP bars and stirrups using Genetic Algorithm and reliability analysis. Engineering Structures, 107, 2016.

[40] Sherwood G.A., Lubell A.S., Bentz E.C., Collins M.P.: One-Way Shear Strength of Thick Slabs and Wide Beams. ACI Structural Journal, vol. 103, Issue 6, 2006.

[41] Szumigała M., Pawłowski D.: Zastosowanie kompozytowych prętów zbrojeniowych w konstrukcjach budowlanych, Przegląd Budowlany, 3/2014.

[42] Thomas J., Ramadass S.: Parametric Study of Shear Strength of Concrete Beams Reinforced with FRP Bars, Journal of The Institution of Engineers (India): Series A, 97(3), 2016.

[43] Tottori S., Wakui H.: Shear capacity of RC and PC beams using FRP reinforcement. In: Nanni A, Dolan C, editors. ACI SP-138. Detroit, Michigan: American Concrete Inst; 1993.

[44] Tureyen A.K., Frosch R.J.: Concrete shear strength: another perspective. ACI Structural Journal, vol. 10, no. 5, 2003.

[45] Valivonis J., Budvytis B., Atutis M., Atutis E., Juknevičius L.: Study of shear resistance of fiber-reinforced polymer-reinforced concrete beams. Advances in Mechanical Engineering, vol. 7(7), 2015.

[46] Wegian F.M., Abdalla H.A.: Shear Capacity of Concrete Beams Reinforced with Fiber Reinforced Polymers.Composite Structure, 71(1), 2005.

[47] Wiater A., Rajchel M., Siwowski T.: Badania płyt pomostu z betonu lekkiego zbrojonego prętami kompozytowymi GFRP. Czasopismo Inżynierii Lądowej, Środowiska i Architektury/ Journal of Civil Engineering, Environment and Architecture, t. XXXII, z. 62 (4/15), październik-grudzień 2015, s. 469-492.

[48] Yousif A.R.: Shear Strength Of Large FRP-Reinforced Concrete Beams Without Shear Reinforcement. ZANCO Journal for Pure and Applied Sciences, vol. 27, no. 3, 2015.

[49] Zhang T., Visintin P., Oehlers D.: Shear strength of RC beams without web reinforcement. Australian Journal of Structural Engineering, vol. 17(1), 2016. 
[50] Zsutty T.C.: Beam Shear Strength Prediction by Analysis of Existing Data. ACI Journal Proceedings, vol. 65, no. 11, 1968.

\section{SHEAR CAPACITY OF CONCRETE MEMBERS REINFORCED WITH FRP REBARS IN THE LIGHT OF SELECTED DESIGN PROCEDURES}

\section{S u m m a r y}

FRP (fibre reinforced polymer) rebars due to high strength and excellent corrosion resistance, are a promising alternative for conventional steel reinforcement. The particular issue to be solved in designing of FRP reinforced concrete element is the prediction of shear capacity. Shear behaviour of steel reinforced concrete is a complex phenomenon. When using a FRP composite as reinforcement, the shear mechanism is different due to linearly elastic stress-strain relation and anisotropic bar properties. The main goal of the paper is the revision of the shear design equations for concrete members reinforced with FRP bars without stirrups. The shear prediction models have been grouped into three categories: (I) modification to design equations for the steel reinforced construction, (II) modification existing procedure for FRP reinforced concrete members, (III) new calculation methods based on experiment database and advanced calculation tools. In this study the analysis on different parameters affecting shear strength such as geometry of element, shear span to depth ratio, longitudinal reinforcement ratio, FRP modulus of elasticity and concrete strength have been taken into consideration. The several codes and models in predicting shear strength of concrete members reinforced with FRP rebars have been compared, and the discrepancies and compatibilities have been established. The procedures including reduction factor for lightweight concrete have been also analysed and compared with experimental results from own studies. The result of this research indicates that the shear strength prediction of FRP reinforced members without stirrups needs much more extensive study, especially when lightweight concrete is used.

Keywords: non-metallic reinforcement, FRP composite, shear strength, design procedure, lightweight concrete

Przesłano do redakcji: $24.03 .2017 \mathrm{r}$.

Przyjęto do druku: 30.06 .2017 r. 